\title{
Antibacterial Activity of Root Canal Filling Materials for Primary Teeth: Zinc Oxide and Eugenol Cement, Calen Paste Thickened with Zinc Oxide, Sealapex and EndoREZ
}

\author{
Alexandra Mussolino de QUEIROZ1 \\ Paulo NELSON-FILHO ${ }^{1}$ \\ Léa Assed Bezerra da SILVA ${ }^{1}$ \\ Sada Assed ${ }^{1}$ \\ Raquel Assed Bezerra da SILVA ${ }^{1}$ \\ Izabel Yoko ITO $^{2}$ \\ ${ }^{1}$ Department of Pediatric Clinic, Preventive and Community Dentistry, Ribeirão Preto Dental School, \\ University of São Paulo, Ribeirão Preto, SP, Brazil \\ ${ }^{2}$ Department of Clinical Analysis, Toxicology and Bromatology, School of Pharmaceutical Sciences of Ribeirão Preto, \\ University of São Paulo, Ribeirão Preto, SP, Brazil
}

\begin{abstract}
This study evaluated in vitro the antibacterial activity of 4 root canal filling materials for primary teeth - zinc oxide and eugenol cement (ZOE), Calen paste thickened with zinc oxide (Calen/ZO), Sealapex sealer and EndoREZ sealer - against 5 bacterial strains commonly found in endodontic infections (Kocuria rhizophila, Enterococcus faecalis, Streptococcus mutans, Escherichia coli and Staphylococcus aureus) using the agar diffusion test (agar-well technique). Calen paste, $1 \%$ chlorhexidine digluconate (CHX) and distilled water served as controls. Seven wells per dish were made at equidistant points and immediately filled with the test and control materials. After incubation of the plates at $37^{\circ} \mathrm{C}$ for $24 \mathrm{~h}$, the diameter of the zones of bacterial growth inhibition produced around the wells was measured (in $\mathrm{mm}$ ) with a digital caliper under reflected light. Data were analyzed statistically by analysis of variance and Tukey's post-hoc test $(\alpha=0.05)$. There were statistically significant differences $(p<0.0001)$ among the zones of bacterial growth inhibition produced by the different materials against all target microorganisms. K. rhizophila was inhibited more effectively $(\mathrm{p}<0.05)$ by ZOE, while Calen/ZO had its highest antibacterial activity against $E$. faecalis $(\mathrm{p}<0.05)$. S. mutans was inhibited by Calen/ZO, Sealapex and ZOE in the same intensity $(\mathrm{p}>0.05)$. E. coli was inhibited more effectively $(\mathrm{p}<0.05)$ by ZOE, followed by Calen/ZO and Sealapex. Calen/ZO and ZOE were equally effective $(\mathrm{p}>0.05)$ against $S$. aureus, while Sealapex had the lowest antibacterial efficacy $(\mathrm{p}<0.05)$ against this microorganism. EndoREZ presented antibacterial activity only against $K$. rhizophila and $S$. aureus. The Calen paste and Calen/ZO produced larger zones of inhibition than $1 \%$ CHX when the marker microorganism was $E$ faecalis. In conclusion, the in vitro antibacterial activity of the 4 root canal filling materials for primary teeth against bacterial strains commonly found in endodontic infections can be presented in a decreasing order of efficacy as follows: ZOE $>$ Calen/ZO $>$ Sealapex $>$ EndoREZ.
\end{abstract}

Key Words: Calen paste, Sealapex, EndoREZ, zinc oxide and eugenol cement, antibacterial activity.

\section{INTRODUCTION}

The endodontic infection in primary teeth with pulp necrosis and apical periodontitis is of polymicrobial nature with predominance of anaerobic bacteria (1), which are disseminated within the root canal system (i.e., the dentinal tubules, lateral canals, accessory canals, secondary canals, apical delta ramifications, apical foramen and apical root cementum surface) and physiological resorptive areas on the external apical root surface (extraradicular infection) (2), pulpectomies being necessary to treat these cases (3). However, as

Correspondence: Profa. Dra. Alexandra Mussolino de Queiroz, Dertamento de Clínica Infantil, Odontologia Preventiva e Social, Faculdade de Odontologia de Ribeirão Preto, USP, Avenida do Café, S/N, 14040-904 Ribeirão Preto, SP, Brasil. Tel: +55-3602-4116. Fax: +55-16-3633-0999. e-mail: amqueiroz@forp.usp.br 
these microorganisms may persist even after biomechanical preparation and use of intracanal dressing (4), root canal filling materials should be able to eliminate residual pathogens, neutralize their toxic products and prevent canal reinfection to in order to create a favorable environment for the healing process to proceed (5). It is therefore important that root canal filling materials used in primary teeth have antimicrobial activity (6-11) and the antimicrobial spectrum of action of these materials should be investigated. The agar diffusion test has been widely used for such purpose $(5-10,12-14)$.

This study evaluated the in vitro antibacterial activity of 4 root canal filling materials for primary teeth - zinc oxide and eugenol cement (ZOE), Calen paste thickened with zinc oxide (Calen/ZO), Sealapex sealer and EndoREZ sealer - against 5 bacterial strains commonly found in endodontic infections.

\section{MATERIAL AND METHODS}

The in vitro antibacterial activity of the following materials against 5 reference strains of bacteria was evaluated by the agar diffusion test (agar-well technique): zinc oxide and eugenol cement (ZOE) (S.S. White Artigos Dentários Ltda., Rio de Janeiro, RJ, Brazil); Calen paste (S.S.White Artigos Dentários Ltda.) thickened with zinc oxide (ZO) (Calen/ZO), Sealapex sealer (Sybron Endo, Glendora, CA, USA); EndoREZ sealer(Ultradent Products Inc., South Jordan, UT, USA). Calen paste, 1\% chlorhexidine digluconate (CHX) (Farmácia Doce Erva, Ribeirão Preto, São Paulo, SP, Brazil) and distilled water served as controls. Table 1 presents the composition and mixing ratio of each material.

The following bacterial strains obtained from the American Type Culture Collection (ATCC) were used as indicator microorganisms in the study: Kocuria rhizophila (ATCC 9341; gram-positive coccus), Enterococcus faecalis (ATCC 10541; gram-positive coccus); Streptococcus mutans (ATCC 25175; gram-positive coccus), Escherichia coli (ATCC 10538; gram-negative bacillus), Staphylococcus aureus (ATCC 6538; gram-positive coccus).

The inocula for the bacterial strains were prepared as follows: saline suspension of the strains cultivated in MHb (Mueller Hinton Broth; Difco, Detroit, MI, USA) was prepared and adjusted to a density equivalent to the 2-3 standard of the McFarland scale for K. rhizophila (formerly known as Micrococcus luteus) and the 0.5 standard for E. coli and S. aureus; dilution in saline of the strains cultivated in TSb (Tryptic Soy Broth; Difco) was done and adjusted to a density equivalent to the 1 standard of the McFarland scale for E. faecalis and the 1-2 standard for $S$. mutans.

For the agar diffusion test (double layer agar-well technique), the MH culture medium (Mueller-HintonMedium, Difco) was used for K. rhizophila, E. coli and $S$. aureus, and the TSA culture medium (Tryptic-SoyAgar; Difco) was used for E. faecalis and S. mutans. In a laminar flow chamber, a base layer composed of 12 $\mathrm{mL}$ of $\mathrm{MH}$ or TSA at $50^{\circ} \mathrm{C}$ was poured into $20 \times 10 \mathrm{~mm}$ sterile Petri dishes. After solidification of the culture medium, a seed layer composed of $8 \mathrm{~mL}$ of MH or TSA at $50^{\circ} \mathrm{C}$ with addition of $10^{6}$ colony forming units (cfu) per milliliter of original inoculum was poured onto the base layer. After solidification of the seed layer, seven 5 -mm-diameter wells were made in each dish by removal of the agar at equidistant points using a sterile straw, and were immediately filled with the test and control materials (one well for each substance). The commercial materials were mixed according to the manufacturers' instructions. The Calen/ZO paste was prepared by mixing $1 \mathrm{~g}$ of Calen paste with $1 \mathrm{~g}$ of $\mathrm{ZO}$ on a sterile glass plate. All materials were used immediately after mixing.

Six repetitions of the test were done, that is, 6 plates were used for each test microorganism. The plates were maintained at room temperature during 2 $\mathrm{h}$ for pre-diffusion of the materials, and then the MH plates were incubated in aerobiosis and the TSA plates were incubated in microaerophilia (candle jar system) at $37^{\circ} \mathrm{C}$ during $24 \mathrm{~h}$. After incubation, the diameter of the zones of bacterial growth inhibition formed around the wells was measured in millimeters with a digital caliper (Mitutoyo, Tokyo, Japan) under reflected light. Data of antibacterial activity of the root canal materials were analyzed statistically by ANOVA and Tukey's post-hoc test at a significance level of 5\% using the Graph Pad Prism 4 software (Graph Pad Inc., San Diego, CA, USA).

\section{RESULTS}

Table 2 shows the diameters (means and standard deviations) of the zones of bacterial growth inhibition zones (in $\mathrm{mm}$ ) obtained for the tested materials. There were statistically significant differences $(p<0.0001)$ among the inhibition zones produced by the tested materials for all bacterial strains. Figure 1 shows the zones of bacterial growth inhibition against the target 
microorganisms (K. rhizophila, E. faecalis, S. mutans, $E$. coli and $S$. aureus) produced by the root canal filling materials for primary teeth (ZOE, Calen/ZO, Sealapex and EndoREZ) and the control materials (Calen paste, $1 \% \mathrm{CHX}$ and distilled water), by the agar diffusion test.
Regarding K. rhizophila, there was no statistically significant difference ( $>0.05)$ among Calen paste, Calen/ZO and Sealapex, which presented zones of bacterial growth inhibition with mean diameters ranging from 20.67 to 21.33 , and neither between $\mathrm{ZOE}$

Table 1. Chemical composition of the experimental and control materials and mixing ratios.

\begin{tabular}{|c|c|c|}
\hline Material & Composition & Mixing ratio \\
\hline $\begin{array}{l}\text { Zinc oxide and eugenol } \\
\text { cement }\end{array}$ & Zinc oxide and eugenol & $\begin{array}{l}1.4 \mathrm{~g} \text { zinc oxide to } \\
0.4 \mathrm{~mL} \text { eugenol }\end{array}$ \\
\hline $\begin{array}{l}\text { Calen paste thickened } \\
\text { with zinc oxide }\end{array}$ & $\begin{array}{c}\text { Calen paste: } 2.5 \mathrm{~g} \text { calcium hydroxide, } 0.5 \mathrm{~g} \text { zinc oxide, } 0.05 \mathrm{~g} \text { colophony } \\
\text { and } 1.75 \mathrm{~mL} \text { polyethylene glycol } 400 \text { (vehicle); Zinc oxide }\end{array}$ & $\begin{array}{l}1 \mathrm{~g} \text { Calen paste to } \\
1 \mathrm{~g} \text { zinc oxide }\end{array}$ \\
\hline Sealapex sealer & $\begin{array}{c}20 \% \text { calcium oxide, } 29 \% \text { bismuth trioxide, } 2.5 \% \text { zinc oxide, } \\
3.0 \% \text { submicron silica, } 2.0 \% \text { titanium dioxide, } 1.0 \% \text { zinc stearate, } \\
3.0 \% \text { tricalcium phosphate, } * 39 \% \text { mixture }\end{array}$ & $\begin{array}{l}\text { Equal amounts } \\
\text { of the base and } \\
\text { catalyst pastes }\end{array}$ \\
\hline EndoREZ sealer & $\begin{array}{l}\text { Zinc oxide, barium sulfate, pigments, } \\
\text { urethane dimethacrylate resin matrix }\end{array}$ & $\begin{array}{l}\text { Equal amounts } \\
\text { of the base and } \\
\text { catalyst paste }\end{array}$ \\
\hline Calen paste (control) & $\begin{array}{l}2.5 \mathrm{~g} \text { calcium hydroxide, } 0.5 \mathrm{~g} \text { zinc oxide, } 0.05 \mathrm{~g} \text { colophony } \\
\text { and } 1.75 \mathrm{~mL} \text { polyethylene glycol } 400 \text { (vehicle) }\end{array}$ & - \\
\hline $\begin{array}{l}1 \% \text { chlorhexidine } \\
\text { digluconate (control) }\end{array}$ & $\begin{array}{l}1 \% \text { chlorhexidine digluconate } \\
\text { Vehicle qsp } 100 \mathrm{~mL}\end{array}$ & - \\
\hline Distilled water (control) & - & - \\
\hline
\end{tabular}

*Ethyl toluene sulfonamide, poly(methylene methyl salicylate) resin, isobutyl salicylate and a pigment.

Table 2. Diameters (in $\mathrm{mm}$ ) of the zones of bacterial growth inhibition against of the bacterial strains.

\begin{tabular}{|c|c|c|c|c|c|c|c|c|c|c|}
\hline \multirow{2}{*}{ Material } & \multicolumn{2}{|c|}{ K. rhizophila } & \multicolumn{2}{|c|}{ E. faecalis } & \multicolumn{2}{|c|}{ S. mutans } & \multicolumn{2}{|c|}{ E. coli } & \multicolumn{2}{|c|}{ S. aureus } \\
\hline & Mean & $\mathrm{SD}$ & Mean & $\mathrm{SD}$ & Mean & $\mathrm{SD}$ & Mean & SD & Mean & $\mathrm{SD}$ \\
\hline Zinc oxide and eugenol cement & 32.67 & 0.51 & 9.00 & 0 & 11.00 & 1.67 & 23.67 & 0.51 & 18.00 & 0.90 \\
\hline Calen paste thickened with zinc oxide & 21.33 & 0.51 & 22.00 & 0 & 12.67 & 1.96 & 16.00 & 0 & 17.00 & 0.89 \\
\hline Sealapex sealer & 20.67 & 1.03 & 13.00 & 1.10 & 11.00 & 0 & 12.00 & 0 & 20.00 & 0.90 \\
\hline EndoREZ sealer & 7.00 & 0 & 0 & 0 & 0 & 0 & 0 & 0 & 8.00 & 0.89 \\
\hline Calen paste (control) & 20.67 & 1.03 & 20.00 & 3.28 & 12.33 & 1.50 & 15.50 & 0.54 & 19.00 & 0.89 \\
\hline $1 \%$ chlorhexidine digluconate (control) & 31.50 & 0.54 & 18.00 & 0.63 & 24.17 & 1.47 & 19.33 & 0.51 & 23.00 & 0.63 \\
\hline Distilled water (control) & 0 & 0 & 0 & 0 & 0 & 0 & 0 & 0 & 0 & 0 \\
\hline
\end{tabular}

The values are expressed as means of 6 repetitions and standard deviations (SD). 

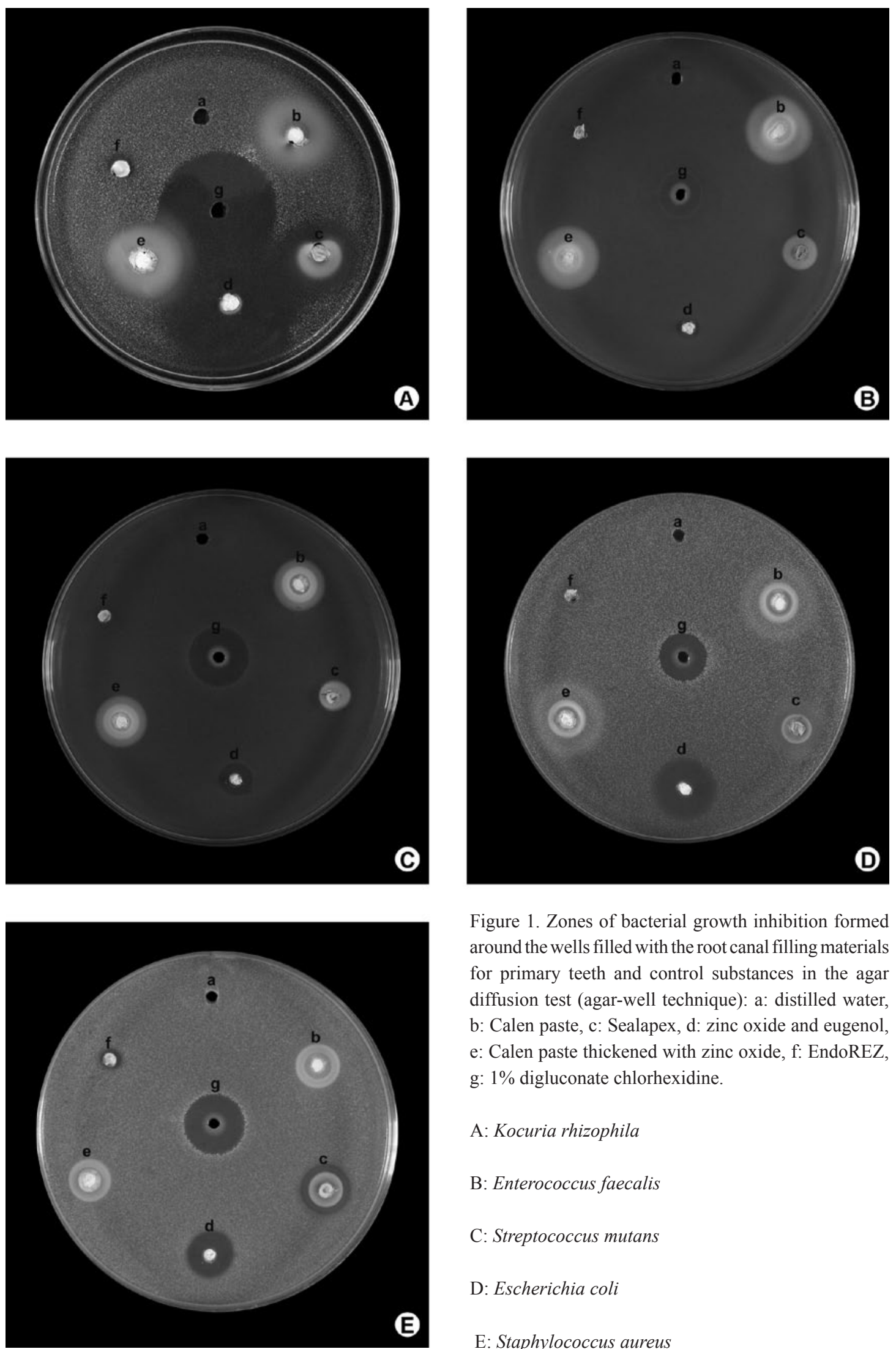

Figure 1. Zones of bacterial growth inhibition formed around the wells filled with the root canal filling materials for primary teeth and control substances in the agar diffusion test (agar-well technique): a: distilled water, b: Calen paste, c: Sealapex, d: zinc oxide and eugenol, e: Calen paste thickened with zinc oxide, f: EndoREZ, g: $1 \%$ digluconate chlorhexidine.

\section{A: Kocuria rhizophila}

B: Enterococcus faecalis

C: Streptococcus mutans

D: Escherichia coli

E: Staphylococcus aureus 
and $\mathrm{CHX}(\mathrm{p}>0.05)$, which presented zones of bacterial growth inhibition with diameters of 32.67 and $31.5 \mathrm{~mm}$, respectively. EndoREZ produced inhibition zones with mean diameter of $7 \mathrm{~mm}$.

The largest mean zones of bacterial growth inhibition against $E$. faecalis were produced by Calen/ZO, followed by Calen paste and 1\% CHX (22, 20 and 18 $\mathrm{mm}$ diameter, respectively). There was no statistically significant difference $(p>0.05)$ between Calen paste and Calen/ZO, and neither between Calen paste and 1\% $\mathrm{CHX}$, as for their antibacterial activity against this microorganism. Statistically significant difference $(\mathrm{p}<0.05)$ was found between Calen/ZO (22 mm diameter) and 1\% CHX (18 mm diameter). EndoREZ and distilled water did not show antibacterial activity. Sealapex and ZOE presented intermediate antibacterial activity, with mean zones of bacterial growth inhibition of 13.00 and $9.00 \mathrm{~mm}$ diameter, respectively, statistically different $(p<0.05)$ from each other.

In the dishes seeded with $S$. mutans, no significant difference $(p>0.05)$ was observed between Calen paste, Calen/ZO, Sealapex and ZOE, which produced mean zones of bacterial growth inhibition of 12.33, 12.67, 11.00 and $11.00 \mathrm{~mm}$ diameter, respectively. The largest mean zone of bacterial growth inhibition $(\mathrm{p}<0.05)$ was produced by $1 \% \mathrm{CHX}$ ( $24.17 \mathrm{~mm}$ diameter), which differed significantly from the other materials. EndoREZ and distilled water did not present antimicrobial activity.

Regarding E. coli, no statistically significant difference $(p>0.05)$ was found between Calen paste and Calen/ZO, which produced mean zones of bacterial growth inhibition of 15.50 and $16.00 \mathrm{~mm}$ diameter, respectively, and neither between EndoREZ and distilled water, which did not present antibacterial activity. ZOE and $1 \% \mathrm{CHX}$ presented the largest mean zones of bacterial growth inhibition (23.67 and $19.33 \mathrm{~mm}$ diameter, respectively), with statistically significant difference between them $(\mathrm{p}<0.05)$.

The diameters of the zones of bacterial growth inhibition produced by the root canal filling materials against $S$. aureus were the following: $23 \mathrm{~mm}(1 \%$ CHX), $20 \mathrm{~mm}$ (Sealapex), $19 \mathrm{~mm}$ (Calen paste), $18 \mathrm{~mm}$ (ZOE), $17 \mathrm{~mm}$ (Calen/ZO) and $8 \mathrm{~mm}$ (EndoREZ). There were no statistically significant differences $(p>0.05)$ between the following pairs of materials: Calen paste $x$ Sealapex, Calen paste x ZOE and Calen/ZO x ZOE. Statistically significant difference $(\mathrm{p}<0.05)$ was found between Sealapex (20 mm diameter) and ZOE (18 mm diameter), and between Calen paste (19 mm diameter) and Calen/ZO (17 mm diameter).

The antibacterial activity of the root canal filling materials for primary teeth against the 5 bacterial strains can be summarized as follows: K. rhizophila: ZOE > Calen/ZO = Sealapex $>$ EndoREZ; E. faecalis: Calen/ZO $>$ Sealapex $>$ ZOE $>$ EndoREZ; S. mutans: Calen $/ Z O=$ Sealapex $=$ ZOE $>$ EndoREZ; . c coli: $Z$ OE $>$ Calen $/ Z O$ $>$ Sealapex $>$ EndoREZ; S. aureus: Sealapex $>$ ZOE $=$ Calen/ZO $>$ EndoREZ. The signal "=" indicates absence of statistically significant difference. Regardless of the microorganism, ZOE showed the highest antibacterial activity, followed by Calen/ZO, Sealapex and EndoREZ.

\section{DISCUSSION}

In the present study, ZOE showed antibacterial activity against all test microorganisms. This material produced the largest zones of bacterial growth inhibition against $K$. rhizophila and E. coli, and the smallest zones of bacterial growth inhibition against $E$. faecalis. Similar results have been reported (14).

Apart from K. rhizophila, which is a microorganism with low intrinsic resistance, the largest zones of bacterial growth inhibition were formed around E. coli (gram-negative bacillus). These results agree with those of Tchaou et al. (6), who observed that ZOE inhibited more effectively gram-negative than gram-positive bacteria.

Savioli et al. (15) evaluated the antimicrobial activity of a ZOE-based root canal filling material for permanent teeth (Grossman's sealer) and its components against different microbial strains using the double layer well-diffusion method, and found that the eugenol component inhibited K. rhizophila, E. faecalis, S. mutans, E. coli and $S$. aureus, which were also evaluated in the present study. ZO alone inhibited only the growth of $S$. sobrinus and E. coli. Perhaps the fact that E. coli was inhibited by both eugenol and ZO may explain why in the present study ZOE produced the largest bacterial growth inhibition zones against $E$. coli $(23.67 \mathrm{~mm}$ diameter), even larger than those produced by $1 \% \mathrm{CHX}$ (19.33 mm diameter). Several authors $(5,10,16)$ have attributed the antimicrobial effects of ZOE to eugenol.

The pre-incubation, which consisted of maintaining the culture media innoculated for about $2 \mathrm{~h}$ at room temperature, was an important factor to evince the antimicrobial activity of the calcium hydroxide pastes $(5,14)$.

The antibacterial activity of Calen paste has been 
extensively demonstrated $(4,5,14,17)$. In the present study, the Calen paste presented antibacterial activity against all test microorganisms with the diameters of the zones of bacterial growth inhibition ranging from 12.33 to $20.67 \mathrm{~mm}$. In order to be used as a root canal filling material for primary teeth, the Calen paste must be thickened with $\mathrm{ZO}$, and the antibacterial activity of this material had not yet been evaluated. Our findings showed that Calen/ZO had antibacterial activity against all test microorganisms with the diameters of inhibition zones ranging from 12.67 to $22.00 \mathrm{~mm}$.

Comparing the diameters of the zones of bacterial growth inhibition produced by Calen paste alone or thickened with ZO, it was observed that slightly larger inhibition zones were formed around Calen/ZO, except for $S$. aureus. Therefore, it may be inferred that the addition of ZO to thicken the Calen paste did not interfere in its antimicrobial activity, with a mild increase of this property. It might be explained by the fact that $\mathrm{ZO}$ also presents antibacterial activity (18). Leonardo et al. (5) has shown that ZO associated with water inhibited the growth of K. rhizophila, E. faecalis, S. mutans, E. coli, $S$. aureus, S. epidermidis and Pseudomonas aeruginosa.

E. faecalis is a facultative anaerobic gram-positive coccus that is considered as one of the most resistant microorganisms to calcium hydroxide-based intracanal medications (19). However, in the present study, Calen paste and Calen/ZO produced the largest zones of bacterial growth inhibition against this pathogen.

Sealapex has been indicated as a root canal filling material for primary teeth (11). In the present investigation, Sealapex showed antibacterial activity against $K$. rhizophila, E. faecalis, S. mutans, E. coli and S. aureus, as reported elsewhere (5). These findings are in accordance with those of Mickel et al. (16) and Bodrumlu and Semiz (12), which evaluated the antibacterial activity of endodontic sealers against E. faecalis, using the using the agar diffusion test. In all experiments, Sealapex showed antibacterial activity against this microorganism. On the other hand, Miyagak et al. (13) did not observe antimicrobial activity of Sealapex against $E$. faecalis, S. aureus and Candida albicans, using the agar diffusion test. This result is probably due to the fact no prediffusion was done in their study, which is a step of the methodology that permits the dissociation and diffusion of the calcium hydroxide contained in the pastes and sealers based on this substance (5).

The use of methacrylate-based sealers as root canal filling materials for primary teeth was first proposed by Woods et al. (20) in the 1980s' after observing biological compatibility and phagocytosis at the same rate of the physiological root resorption of the primary teeth. EndoREZ was evaluated in the present study for this reason.

Few studies have evaluated the antimicrobial efficacy of EndoREZ. A previous study using the agar diffusion test found that EndoREZ did not present antimicrobial activity against $E$. faecalis, E. coli, Micrococcus luteus, $S$. aureus, S. epidermidis, P. aeruginosa and Candida albicans (7). Using the agar diffusion test as well, Eldeniz et al. (9) did not observe antibacterial activity of EndoREZ against E. faecalis, $S$. aureus and $P$. aeruginosa, and mild antibacterial activity against these microorganisms was observed only when the direct contact test was used. In the present investigation, EndoREZ exhibited antibacterial activity, though small, against $K$. rizhophila (7 $\mathrm{mm}$ diameter) and $S$. aureus $(8$ $\mathrm{mm}$ diameter).

Based on the statistically significant differences among the root canal filling materials for primary teeth evaluated in this study, it may be inferred that overall, ZOE presented the highest antibacterial activity against the test microorganisms, followed by Calen/ZO and Sealapex. EndoREZ presented the lowest antibacterial activity among the tested materials. However, it is important to mention this alleged superior antibacterial activity of ZOE compared to Calen/ZO was partially due to the fact that $K$. rizhophila was more effectively inhibited by ZOE than by Calen/ZO, with diameters of the zones of bacterial growth inhibition of $32.67 \mathrm{~mm}$ and $21.33 \mathrm{~mm}$, respectively. However, it is known that the intrinsic resistance of $K$. rizhophila is considerably low, which means that an intense antibacterial activity is not necessary to inactivate this microorganism. E. coli was another microorganism that was effectively inhibited by ZOE than by Calen/ZO, with the formation of zones of bacterial growth inhibition with diameters of 23.67 $\mathrm{mm}$ and $16 \mathrm{~mm}$ diameter, respectively. In spite of the statistical significance, the zones of bacterial growth inhibition produced by Calen/ZO were not small against microorganism. However, when the indicator microorganism was $E$. faecalis, a very resistant microorganism that is present in root canals of primary teeth with necrotic pulp and apical periodontitis and is commonly found in teeth that need endodontic retreatment, Calen/ $\mathrm{ZO}$ had a significantly higher antibacterial activity than 
ZOE, with the formation of zones of bacterial growth inhibition of 22 and $9 \mathrm{~mm}$ diameter, respectively. In this case, an intense antibacterial activity is essential to inactivate this microorganism. There was no statistically significant difference between the antibacterial activity of ZOE and Calen/ZO against S. mutans and S. aureus.

Based on the obtained results and within the limitations of the methodology, it may be concluded that the in vitro antibacterial activity against the tested bacterial strains in a decreasing order was: ZOE, Calen/ ZO, Sealapex and EndoREZ.

\section{RESUMO}

Este estudo avaliou in vitro a atividade antibacteriana de 4 materiais obturadores de canais radiculares de dentes decíduos - cimento de óxido de zinco e eugenol (OZE), pasta Calen espessada com óxido de zinco (Calen/OZ), cimento Sealapex e cimento EndoREZ - sobre 5 cepas bacterianas comumente encontradas em infecções endodônticas: Kocuria rhizophila, Enterococcus faecalis, Streptococcus mutans, Escherichia coli e Staphylococcus aureus, usando o teste de difusão em ágar (técnica do poço). A pasta Calen, digluconato de clorexidina a $1 \%(\mathrm{CHX})$ e água destilada foram usados como controle. Sete poços por placa foram preparados em pontos eqüidistantes e imediatamente preenchidos com os materiais experimentais e controle. Após incubação das placas a $37^{\circ} \mathrm{C}$ por $24 \mathrm{~h}$, o diâmetro dos halos de inibição do crescimento bacteriano formados ao redor dos poços foi medido (em $\mathrm{mm}$ ) com um paquímetro digital sob luz refletida. Os dados obtidos foram submetidos à análise de variância e ao pós-teste de Tukey $(\alpha=0,05)$. Com relação à atividade antibacteriana, evidenciaramse diferenças estatisticamente significantes $(p<0,0001)$ entre os halos de inibição formados pelos diferentes materiais, para todos os microrganismos avaliados. A $K$. rhizophila foi inibida mais eficazmente pelo OZE $(\mathrm{p}<0,05)$, enquanto que o E. faecalis foi inibido mais eficazmente pela Calen/OZ $(\mathrm{p}<0,05)$. O S. mutans foi inibido pela Calen/OZ, cimento Sealapex e OZE na mesma intensidade $(\mathrm{p}>0,05)$. A $E$. coli foi inibida mais eficazmente pelo OZE, seguido pela Calen/OZ e pelo cimento Sealapex $(\mathrm{p}<0,05)$. O $S$. aureus foi inibido pela Calen/OZ e OZE na mesma intensidade ( $p>0,05)$, e menos intensamente pelo cimento Sealapex $(p<0,05)$. O cimento EndoREZ apresentou atividade antibacteriana apenas frente a $K$. rhizophila e ao $S$. aureus. A pasta Calen e a Calen/ $\mathrm{OZ}$ ocasionaram halos de inibição maiores que a CHX quando o microrganismo indicador foi o E. faecalis. Pode-se concluir que a atividade antibacteriana, in vitro, dos 4 materiais obturadores de canais radiculares de dentes decíduos sobre cepas bacterianas comumente encontradas em infecções endodônticas pode ser apresentada numa ordem decrescente de eficácia da seguinte maneira: OZE $>$ Calen $/ \mathrm{OZ}>$ Sealapex $>$ EndoREZ.

\section{REFERENCES}

1. Ruviére DB, Leonardo MR, da Silva LA, Ito IY, Nelson-Filho P. Assessment of the microbiota in root canals of human primary teeth by checkerboard DNA-DNA hybridization. J Dent Child
2007;74:118-123.

2. Rocha CT, Rossi MA, Leonardo MR, Rocha LB, Nelson-Filho P, Silva LA. Biofilm on the apical region of roots in primary teeth with vital and necrotic pulps with or without radiographically evident apical pathosis. Int Endod J 2008;41:664-669.

3. Carrotte PV, Waterhouse PJ. A clinical guide to endodonticsupdate part 2. Br Dent J 2009;206:133-139.

4. Faria G, Nelson-Filho P, Freitas AC, Assed S, Ito IY. Antibacterial effect of root canal preparation and calcium hydroxide paste (Calen) on intracanal dressing in primary teeth with apical periodontitis. J Appl Oral Sci 2005;13:351-355.

5. Leonardo MR, Silva LAB, Tanomaru Filho M, Bonifácio KC, Ito IY. In vitro evaluation of antimicrobial activity of sealers and pastes used in endodontics. J Endod 2000;26:391-394.

6. Tchaou WS, Turng BF, Minah GE, Coll JA. Inhibition of pure cultures of oral bacteria by root canal filling materials. Pediatr Dent 1996;18:444-449.

7. Sipert CR, Hussne RP, Nishiyama CK, Torres SA. In vitro antimicrobial activity of Fill Canal, Sealapex, Mineral Trioxide Aggregate, Portland cement and EndoREZ. Int Endod J 2005;38:539-543.

8. Amorim LF, Toledo OA, Estrela CR, Decurcio DA, Estrela C. Antimicrobial analysis of different root canal filling pastes used in pediatric dentistry by two experimental methods. Braz Dent J 2006; 17:317-322.

9. Eldeniz AU, Erdemir A, Hadimli HH, Belli S, Erganis O. Assessment of antibacterial activity of EndoREZ. Oral Surg Oral Med Oral Pathol Oral Radiol Endod 2006;102:119-126.

10. Reddy S, Ramakrishna Y. Evaluation of antimicrobial efficacy of various root canal filling materials used in primary teeth: a microbiological study. J Clin Pediatr Dent 2007;31:193-198.

11. Sari S, Okte Z. Success rate of Sealapex in root canal treatment for primary teeth: 3-year follow-up. Oral Surg Oral Med Oral Pathol Oral Radiol Endod 2008; 105:e93-e96.

12. Bodrumlu E, Semiz M. Antibacterial activity of a new endodontic sealer against Enterococcus faecalis. J Can Dent Assoc 2006;72:637

13. Miyagak DC, de Carvalho EM, Robazza CR, Chavasco JK, Levorato GL. In vitro evaluation of the antimicrobial activity of endodontic sealers. Braz Oral Res 2006;20:303-306.

14. Tanomaru-Filho M, Tanomaru JM, Barros DB, Watanabe E, Ito IY. In vitro antimicrobial activity of endodontic sealers, MTA-based cements and Portland cement. J Oral Sci 2007;49:41-45.

15. Savioli RN, Pecora JD, Mian H, Ito IY. Evaluation of the antimicrobial activity of each component in Grossman's sealer. Braz Oral Res 2006;20:127-131.

16. Mickel AK, Nguyen TH, Chogle S. Antimicrobial activity of endodontic sealers on Enterococcus faecalis. J Endod 2003;29:257-258.

17. Soares JA, Leonardo MR, Tanomaru Filho M, Silva LA, Ito IY. Residual antibacterial activity of chlorhexidine digluconate and camphorated p-monochlorophenol in calcium hydroxide-based root canal dressings. Braz Dent J 2007;18:8-15.

18. Jones N, Ray B, Ranjit KT, Manna AC. Antibacterial activity of $\mathrm{ZnO}$ nanoparticle suspensions on a broad spectrum of microorganisms. FEMS Microbiol Lett 2008;279:71-76.

19. Onçag O, Cogulu D, Uzel A. Efficacy of various intracanal medicaments against Enterococcus faecalis in primary teeth: an in vivo study. J Clin Pediatr Dent 2006;30:233-237.

20. Woods RL, Kildea PM, Gabriel SA, Freilich LS. A histologic comparison of Hydron and zinc oxide-eugenol as endodontic filling materials in the primary teeth of dogs. Oral Surg Oral Med Oral Pathol 1984;58:82-93. 